Acta Scientifica Naturalis

Former Annual of Konstantin Preslavsky University - Chemistry, Physics, Biology, Geography Journal homepage: http://www.shu.bg

Received: 30.10 .2016

Accepted: 11.01.2017

\title{
Covalent immobilization of rabbit-antiaflatoxin-antibodies onto the poly-acrylamide- acrylonitrile as well as hybrid material UREASIL and developing an optical immunosensor
}

\author{
M. Slavova ${ }^{1,2,3}$, R. Georgieva-Nikolova ${ }^{3}, \mathrm{H}_{\text {. Hristov }}{ }^{3}$, M. Nikolova $^{4}$
}

1 - Institute of Electrochemistry and Energy Sources, Bulgarian Academy of Science, Sofia, Bulgaria

2 - Department of Machine Elements and Chemistry, Faculty of Transport Management, Todor Kableshkov University of Transport, Sofia, Bulgaria

3 - Department of Inorganic Chemistry and Chemical Education, Faculty of Natural Sciences, Shumen University "Konstantin Preslavski", Shumen, Bulgaria

${ }^{4}$ - Middlesex University, School of Health and Education - London, United Kingdom e-mail - mslavova@bas.bg

\begin{abstract}
The aim of this work is to describe a covalent immobilization of antibodies onto the polyacrylamide-acrylonitrile or hybrid material UREASIL and creation of optical immunosensor for determination of aflatoxin B1. For this purpose, mouse-anti-aflatoxin B1 antibodies with oxidized carbohydrate moieties were covalently immobilized on the membranes of polyacrylamidepolyacrylonitrile copolymer, as well as the hybrid material UREASIL. To determine the affinity binding of the immobilized antibody with aflatoxin B1 was used "sandwich" method. Associated with the immobilized antibody sought ingredients interact with a surplus of secondary signal antibodies. The described method has been developed as a model system, which can easily be applied for the determination of aflatoxins in samples of different origin. To the best of our knowledge, this is the first study to show that in the establishment of biosensor was used hybrid material UREASIL.
\end{abstract}

Keywords: aflatoxin B1, immunosensor, optical Biosensor, immobilization, antibody

\section{Introduction}

Aflatoxins are natural mycotoxins that enter the food chain by contamination of crops and nuts, potentially posing carcinogenic risks to animal and human health. In fact, the European Committee Regulations (ECR) has established the maximum acceptable level of aflatoxin B1 (AFB1) in cereals, peanuts and dried fruits for direct human consumption: $4 \mathrm{ng} / \mathrm{g}$ for total aflatoxins (AFB1, AFG1, AFB2, AFG2) and 2ng/g for AFB1 alone (1). Aflatoxin B1 is the most common mycotoxin produced by strains of Aspergillus flavus and Aspergillus parasiticus that grow on food crops during their production and storage. It exhibits carcinogenic, teratogenic, mutagenic and immunosuppressive properties and has been regarded as a human carcinogen by the International Agency for Research on Cancer (2).

Analytical methodology must allow the determination of aflatoxins at least below the specific regulatory levels (3). The measurement of antibody or antigen concentrations based on biospecific 
recognition interactions such as immunoassay and biosensors, has been considered a major analytical method used in clinical diagnosis, environment, and biochemical studies and has generated much interest due to its cost-effectiveness, sensitivity and specificity (4).

Immunosensing is a very active research field. The inherent combination of the exquisite molecular recognition ability of antibodies and the philosophy of rapid, continuous, reversible and automatic analysis of chemical sensors utilized in immunosensors is very useful in many fields (5). In this sense, batch immunoassays can solve analytical problems that require a high number of determinations, while immunosensing is the better choice when automation and rapid results are needed (6).

The general strategy for immunosensor construction is to place the biological material in close contact with the transducer in order to obtain high sensitivity and to minimise the time of measurement.

The aim of this work is to describe development of new immunosensor for determination of AFB1 with participation of a poly-acrylamide-acrylonitrile or hybrid material UREASIL.

\section{Materials and Methods}

O,O-bis(2-aminopropyl)-polypropylene glycol-blockpolyethylene glycol-block-polypropylene glycol500 (Jeffamine ED-600, Fluka) was dried under a dynamic vacuum before use. 3-Isocyanate propyltriethoxysilane (ICPTES, Aldrich), tetrachloroauric acid (Aldrich), trisodium citrate dihydrate (Aldrich), absolute ethanol (Riedel-deHaën), citric acid monohydrate (Merck) were used as received. Distilled water with a resistance around $18 \mathrm{MS} / \mathrm{cm}$ was used for the preparation of diluted aqueous solutions.Monoclonal antibodies against $\mathrm{AFB}_{1}$ from rabbit (r-anti-AFB1) and monoclonal antibodies against AFB1 from mouse (r-anti-AFB1) were purchased from Sigma (St Louis, MO, USA). All chemicals and solvents used were of analytical grade and were used without further proceeding.

Obtaining of membranes of poly-acrylonitrile-polyacrylamide and of UREASIL

The particles from copolymer of poly-acrylonitrile-polyacrylamide were obtained according to the method used in. Then $0.100 \mathrm{~g}$ from obtained copolymer was diluted in $1 \mathrm{~mL}$ dimethylformamide (DMF) and the solution was stirred for 15 min on magnetic stirrer. After dilution 1:1 with anizol the prepared polymer solution was cast on a thin layer.

The synthesis of the UREASIL monoliths included several steps. At the first step stoichiometric amounts of Jeffamine and ICPTES $(1: 2 ; R=2.0)$ were mixed in a glass vessel under stirring at $200 \mathrm{rpm}$ for $10 \mathrm{~min}$, so that the rapid uncatalyzed reaction between amino and isocyanate groups forming polyurea linkages took place (7). The obtained material will be referred to hereafter as a conventional ureasilicate precursor. At the second step an additional amount of ICPTES was added in order to adjust the desired molar ratio between ICPTES and Jeffamine in final mixtures. Ethanol was used as a homogenizing agent and was added $5 \mathrm{~min}$ later. The third step consisted of the catalyzed hydrolysis/condensation of the mixture by addition of ammonia or citric acid aqueous solution. The mixture was stirred for $10 \mathrm{~min}$ more and poured into a polystyrene cell, covered with Parafilm R, which was pin-holed after gelation at room temperature. The gelation time varied from $1 \mathrm{~h}$ to 3 days depending on catalyst used and $\mathrm{R}$ value. During the final step the cell with the resulting gel was kept in an oven for two weeks at $40^{\circ} \mathrm{C}$, which assured completion of hydrolysis/condensation reactions and evaporation of residual liquids. This drying process led to sample shrinkages of about $30 \%$ of total volume (8).

Method of oxidation of anti-aflatoxin B1 antibody

The working concentration of monoclonal m-anti-AFB1 was $0.67 \mathrm{mg} / \mathrm{mL}$. The oxidation of carbohydrate moieties of antibody with periodic acid $(0.04 \mathrm{mmol} / \mathrm{L}$ in $0.05 \mathrm{mmol} / \mathrm{L}$ acetate buffer, $\mathrm{pH}$ 5.0) was performed according to Zabrosky and Ogletree. The unreacted periodic acid was removed with $0.025 \mathrm{mmol} / \mathrm{L}$ ethylene glycol. The oxidized antibody was dialyzed against $50 \mathrm{mmol} / \mathrm{L}$ phosphate buffer with pH 6.0 for 18-24 h (9).

53 
Covalent immobilization of oxidized m-anti-AFB1 on polymer film

The immobilization of m-anti-AFB1 was performed in the following manner: $5 \mathrm{~mL}$ of oxidized dialytic solution of antibody was added to a $100 \mu \mathrm{g}$ of membranes. The process was implemented for 24 hours at $\mathrm{t}=4^{\circ} \mathrm{C}$ in dark (Fig. 1).

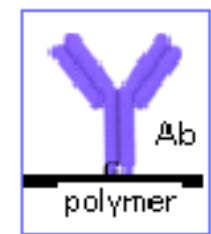

Fig.1. Immobilized antibody

Modified Lowry method:

The protein content was measured using a modified Lowry method (10). The principle behind the Lowry method for determining protein concentrations lies in the reactivity of the peptide nitrogens with the copper [II] ions under alkaline conditions, and the subsequent reduction of the FolinCiocalteay phosphomolybdicphosphotungstic acid to heteropolymolybdenum blue by the coppercatalyzed oxidation of aromatic acids.

First, reagent A: $2 \% \mathrm{Na}_{2} \mathrm{CO}_{3}$ in $0,1 \mathrm{~N} \mathrm{NaOH}$, reagent B: $1 \% \mathrm{CuSO}_{4} \cdot 5 \mathrm{H}_{2} \mathrm{O}$ and reagent $\mathrm{C}: 2 \%$ sodium tartrate, were prepared. Reagent $\mathrm{D}$ was prepared by mixing reagents $\mathrm{B}$ and $\mathrm{C}$ in the ratio 1:1. Reagent $\mathrm{D}$ was prepared just prior to use of reagents $\mathrm{A}$ and $\mathrm{D}$ in a ratio of 1:50.

After immobilization, the membrane was put into $1 \mathrm{~mL}$ distilled water. Thereafter were added $5 \mathrm{~mL}$ of reagent $\mathrm{D}$, and the solution was left for 160 minutes with occasional stirring. Then, $0,5 \mathrm{~mL} 1 \mathrm{~N}$ reagent Folin-Chokalteu (fosfomolibdovolframat) were added. After 45 minutes, the absorbance was determined at $750 \mathrm{~nm}$ against a control that contained the same components, but without the immobilized membrane. The amount of protein was determined by the standard. For reference was used a solution of m-anti-AFB1.

Immunosensor for aflatoxin B1 using sandwich immunoassay

A membrane of poly-acrylamide-acrylonitrile or UREASIL with immobilized mouse-antiaflatoxin B1 was washed successively with distilled $\mathrm{H}_{2} \mathrm{O}$, brine, and again with distilled $\mathrm{H}_{2} \mathrm{O}$ and placed in $0.025 \%$ solution of bovine serum albumin for 1 hour to blocking the free surface. After extensive washing with distilled water, the membrane was incubated with the solution described in the standard solutions of AFB1 for 30 minutes and again thoroughly washed with distilled water. On the bottom of the cuvette is placed membrane. The activity of the peroxidase is optically determined by the change in the intensity of the coloration due to the added $\mathrm{H}_{2} \mathrm{O}_{2}$ and o-dianisidine. The amount of enzyme is proportional to the aflatoxin (Fig. 2) (11).

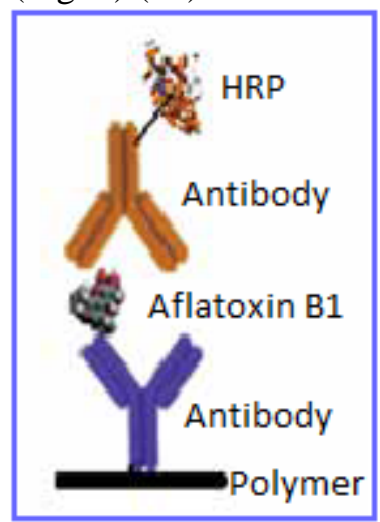

Fig.2. Immunosenzor assay

Recovery of immunosensor

54

Corresponding author: mslavova@bas.bg

DOI: 10.1515/asn-2017-0008
(C2017 “K.Preslavsky”University of Shumen. All rights reserved 
After 20 min treating with citrate-phosphate buffer (containing $4.7 \mathrm{~g} / \mathrm{l}$ citric acid and $9.2 \mathrm{~g} / \mathrm{l}$ disodium hydrogenphosphate, $\mathrm{Na}_{2} \mathrm{HPO}_{4}$ anhydrous) at $\mathrm{pH} 5.0$ the sandwich is destroyed and the sensor is regenerated.

\section{Results and Discussion}

The calibration curve was prepared using the Lowry method, using an m-anti-AFB1 solution at 1 $\mathrm{mg} / \mathrm{mL}$ concentration as a standard protein solution. Out of the solution, the following solutions were prepared (Table 1):

Table 1. Standard solutions for determination of protein according the Lowry's method

\begin{tabular}{|c|c|c|c|c|c|c|c|c|c|c|}
\hline Solution & Control & 1 & 2 & 3 & 4 & 5 & 6 & 7 & 8 & 9 \\
\hline $\begin{array}{c}1 \mathrm{mg} / \mathrm{ml} \\
\text { mouse } \\
\text { IgG }\end{array}$ & - & $0,1 \mathrm{ml}$ & $0,15 \mathrm{ml}$ & $0,2 \mathrm{ml}$ & $0,25 \mathrm{ml}$ & $0,3 \mathrm{ml}$ & $0,35 \mathrm{ml}$ & $0,4 \mathrm{ml}$ & $0,45 \mathrm{ml}$ & $0,5 \mathrm{ml}$ \\
\hline $\mathrm{d} . \mathrm{H}_{2} \mathrm{O}$ & $1 \mathrm{ml}$ & $0,9 \mathrm{ml}$ & $0,85 \mathrm{ml}$ & $0,8 \mathrm{ml}$ & $0,75 \mathrm{ml}$ & $0,7 \mathrm{ml}$ & $0,65 \mathrm{ml}$ & $0,6 \mathrm{ml}$ & $0,55 \mathrm{ml}$ & $0,5 \mathrm{ml}$ \\
\hline
\end{tabular}

To each tube were added $5 \mathrm{~mL}$ reagent $\mathrm{D}$ and, after stirring for 10 minutes at room temperature, to each were added $0,5 \mathrm{~mL} 1 \mathrm{~N}$ solution of Folin-Chokalteu. After 45 minutes, the solutions were tested at $750 \mathrm{~nm}$ photometry against a control (Fig. 3).

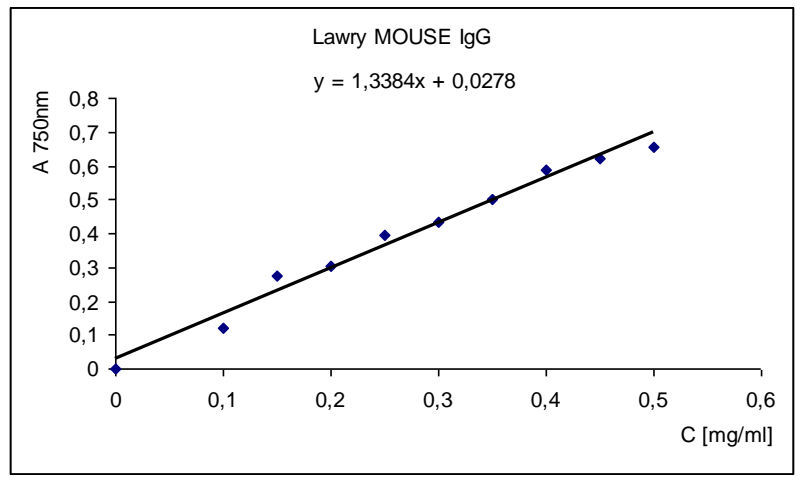

Fig. 3. Calibration curve.

The designated amount is immobilized antibodies to the modified method of Lowry, as a result of which it was found that on smooth copolymer membranes is immobilized $1.228 \mathrm{mg} / \mathrm{g}$ antibodies on the membrane of a porous copolymer $-2,17 \mathrm{mg} / \mathrm{g}$, while on the hybrid material UREASIL- $2,01 \mathrm{mg} / \mathrm{g}$. To determine the affinity binding of the immobilized antibody with AFB1 is used so-called "sandwich" method (Fig. 2). In this method it is connecting to the immobilized antibody with prediluted antigen - AFB1. In the solution for incubation are present and polyclonal rabbit anti-AFB1antibodies related to the enzyme peroxidase. The membrane was placed in a cuvette with a solution containing $\mathrm{H}_{2} \mathrm{O}_{2}$ and o-dianisidine, which initiates a colored enzymatic reaction. Measured absorbance to determine the presence of AFB1 and quantifying it. The analysis is very sensitive.

The observed results are presented in Table 2.

Table 2. Optical results of the analysis of a solution containing 0,01 ng / ml AFB1

\begin{tabular}{|c|c|c|c|}
\hline Membrane material & porous copolymer & smooth copolymer & UREASIL \\
\hline$\Delta \mathrm{A} / \mathrm{min}$ & 0,229 & 0,139 & 0,222 \\
& $* 0,004$ & & \\
\hline
\end{tabular}

55

Corresponding author: mslavova@bas.bg

DOI: $10.1515 /$ asn-2017-0008 
For repeated immersion of the membrane in fresh substrate, after separation of the "sandwich" and rinse $\Delta \mathrm{A} / \mathrm{min}$ sharply reduced, since at $\mathrm{pH}=6$ sandwich separated (* Table 2 ).

\section{Conclusions}

From the obtained results it can be concluded that the principle of the method works.

The described method has been developed as a model system, which can easily be applied for the determination of aflatoxins in samples from various origins.

\section{REFERENCES}

[1]. Europian Commission. Commission Regulation (EC) no. 472/2002 of 12 March 2002. Official Journal of the European Union. L 77, 1-13 and Europian Commission. Commission Regulation (EC) no. 123/2005 of 26 January 2005. Official Journal of the European Union. L 25, 3-5 setting maximum limit for certain contaminants in food stuff.

[2]. Wacoo AP, Wendiro D, Vuzi PC, Hawumba JF. Methods for Detection of Aflatoxins in Agricultural Food Crops. J. Appl. Chem. 2014; 2014:1-15. http://dx.doi.org/10.1155/2014/706291

[3]. Sharma A, Matharu Z, Sumana G, Solanki PR, Kim CG, Malhotra BD. Antibody immobilized cysteamine functionalized-gold nanoparticles for aflatoxin detection Thin Solid Films. 2010; 519 (3):1213-1218. http://dx.doi.org/10.1016/j.tsf.2010.08.071

[4]. Zhang J, Wang J, Zhu J, Xu J, Chen H, Xu D. An electrochemical impedimetric arrayed immunosensor based on indium tin oxide electrodes and silver-enhanced gold nanoparticles. Microchim. Acta. 2008; 163(1):63-70. http://dx.doi.org/10.1007/s00604-008-0944-y

[5]. Beatriz Prieto-Simon, Monika Campas, Silvana Andreescu, Jean-Louis Marty

Trends in Flow-based Biosensing Systems for Pesticide Assessment. Sensors (Basel). 2006; ; 6(10): 1161-1186.

[6]. González-Martínez MA, Puchades R, Maquieira A. Optical immunosensors for environmental moniroring: How far have we come? Anal. Bioanal. Chem. 2007; 387:205-218. http://dx.doi.org/10.1007/s00216-006-0849-8

[7]. M Armand, C Poinsignon, JV Sanches, V de Zea Bermudez U.S. Patent 5283310 (1994)

[8]. VI Boev, A Soloviev, C Silva, M Gomes, D Barber J. Sol-Gel Sci. Techn. 41, 223 (2007)

[9]. Yotova L, Yaneva S. Silica-based hybrid materials as biocompatible coatings for xenobiotics sensors. Bulg. Chem. Commun. 2013; 45:516-521.

[10]. Winters AL, Minchin FR. Modification of the Lowry assay to measure proteins and phenols in covalently bound complexes. Anal. Biochem. 2005; 346(1):43-48.

[11]. Slavova M, Yotova L, Gergova R. Creation of optical immuno-sensor for determination of aflatoxin b1 involving ureasil. Helth and Science. 3(2015)21-24 